OXANA FREYDMAN

Irkutsk State Railway University, Russia

\title{
Marketing and logistical technologies in creating multiplicative effect of territorial development
}

This article is devoted to modern methods and technologies which can be used in development of territorial socio-economic systems. Research in this sphere must serve as the basis of territorial planning. Therefore, it is essential that we determine the necessary number and structure of the technologies used. The combination of marketing and logistical technologies is the most effective and progressive in territorial development.

Modern economic integration needs special attention to be paid to conserving and increasing the indicators of socio-economic development, which is a condition of attracting the investments from outside.

Main indicators of regional and territorial economy characterizing the level of government administration and development of marketing communications are:

- the gross territorial (or national) product;

- the ratio of export and import activity;

- the rate of capitalization of the domestic market fund;

- the revenue of government budget;

- the level of transportation system.

We may conclude that certain factors (which will be presented below) are of high importance for economic development. These factors are logistical in their nature, and include:

- the volume of export and import activities in the structure of gross national revenue;

- the duration of the time period needed for formation of private business;

- availability of foreign or domestic investments for financing various economic processes;

- the level of transportation system development.

Great Britain, Germany, Spain, Italy, the USA, the UAE, and Singapore have used these indicators as basic ones for creative and scientific development, measuring dynamics of gross national revenue. All these indicators reflect the influence of marketing and logistics at effective management. Some of these correlative indices are given below (Tab. 1).

Tab. 1. Indices of social-economic development, 2007

\begin{tabular}{|l|c|c|c|c|c|c|}
\hline \multicolumn{1}{|c|}{ Countries } & $\begin{array}{c}\text { GNP, } \\
\text { \$bln. }\end{array}$ & $\begin{array}{c}\text { Export } \\
\% \text { GNP }\end{array}$ & $\begin{array}{c}\text { Import } \\
\% \text { GNP }\end{array}$ & $\begin{array}{c}\text { Capitalization } \\
\text { rate \% }\end{array}$ & $\begin{array}{c}\text { GDP budget } \\
\text { revenue \% }\end{array}$ & $\begin{array}{c}\text { Rate of econo- } \\
\text { mic growth \% }\end{array}$ \\
\hline Belgium & 352 & 84 & 81 & 20 & 43,7 & 2,9 \\
\hline Belorussia & 23 & 68 & 74 & 28 & 30,6 & 11 \\
\hline
\end{tabular}




\begin{tabular}{|l|r|r|r|r|r|l|}
\hline Germany & 2741 & 38 & 33 & 17 & 28,6 & 1,6 \\
\hline Great Britain & 2124 & 25 & 28 & 17 & 36,6 & 3,1 \\
\hline Greece & 205 & 21 & 29 & 26 & 46,5 & 4,2 \\
\hline Israel & 117 & 44 & 49 & 17 & 41,6 & 4,4 \\
\hline Italy & 1678 & 27 & 26 & 20 & 37,7 & 1,2 \\
\hline Russia & 581 & 35 & 22 & 21 & 27,3 & 7,1 \\
\hline USA & 11712 & 10 & 14 & 18,3 & 17,2 & 4,2 \\
\hline
\end{tabular}

Thus, we may conclude that it essential to use logistical methods for any type of territorial marketing strategies. More exactly, in practice, it is necessary to take into account the set of chosen logistical methods of territorial marketing management based upon existing complex of indices of economic development. Only all the used methods, in their complexity, can be effective and create a multiplicative effect on the territorial economy.

Investigation of logistics management due to the need to regulate social and economic development of the region, where logistics are owned by defining a function as an effective security in the region resources (material, financial, information) as well as their distribution and redistribution. As the underlying factors, beside possession of natural resources that influence the effectiveness of regional development, the following should be indicated: the presence of a developed transport infrastructure in the region; well-functioning industrial and agricultural production; professional and territorial mobility of labor resources; development within and inter-regional exchange of resources; optimal financing of the budget as the basis of the public sector (Fig. 1. Group of factors affecting the efficiency of the region as a whole). This determines the possible success of the region, but only under conditions of effectively organized logistics flows. Before starting the procedure of choosing logistics strategy for the region and considering using different methods of optimization of the regional flows of material, financial, information and human resources, there must be a detailed study and identification of groups of factors influencing the effectiveness of flow of logistics flows. Study of logistics flows and processes is a sequential process, it is organized segmentation of logistic flows on priority grounds, examining them in terms of factor influence and evaluating the effectiveness of management. All the logistics flows in the region can be classified on several grounds:

- on the grounds of resources: material, financial, information, and employment;

- on the basis of input and output : incoming and going;

- on the basis of relationship to the environment of the region: internal and external;

- on the grounds of place of origin: flows procurement inter-system production flow, distribution flow;

- on the industry areas of management.

The greatest attention in research on logistics processes in terms of territory management functions should be given to the analysis of management processes in the public sector, as their specificity is to compare the effectiveness of financing effectively to the needs of the population. Consequently, the priority approach to the study of logistic processes in the public sector should be an analysis of the needs of the population into groups of state and municipal services (Fig. 1). The main types of services can be selected services in the following areas of management:

- the municipal transport;

- housing and communal services and service area cities;

- health, education, policing and public safety; 
As the parameters of the logistic process abroad the following indicators should be used (research company Becton Dickinson based on D. Johnson, « Modern Logistics»):

- customer service;

- the value (level) value stocks;

- the level of costs, logistics, including transport;

- administrative level costs of logistics.

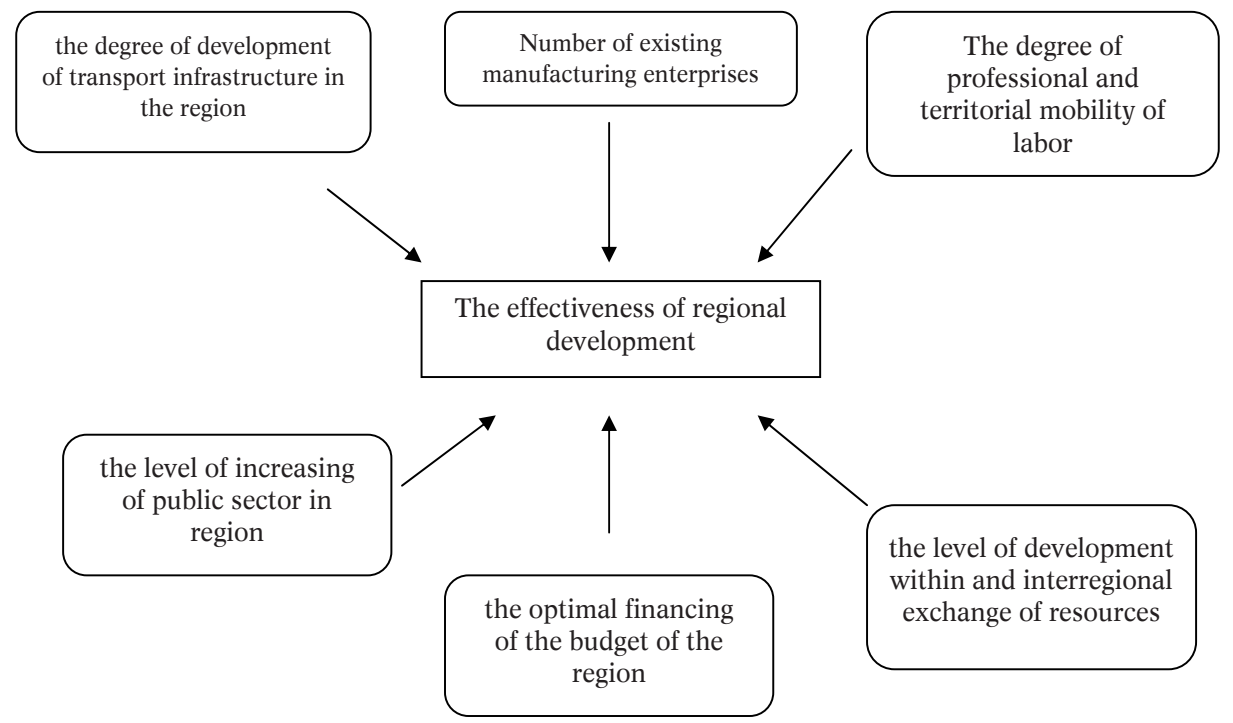

Fig. 1. Group of factors affecting the efficiency of the region

As stated above, the inclusion of methods of logistics in the structure of territorial marketing strategies can lead to a high multiplier effect of local development. The following logical chain can be built:

1. Gross domestic product area is calculated as the product of the number of transactions and average prices in the economy, therefore, between the index of the number of transactions and the level of inflation there is a direct link.

2. The number of completed transactions depends on the speed of their commission, while the speeds depend on many factors, among which we can identify marketing and logistics.

3. In the marketing, information speed can be defined in the course of transactions, the effectiveness of established channels of promotion of production of land, etc.

4. In the logistics, there are such factors as improved transportation, which is impossible without an efficient transport infrastructure, without having to create transportation and logistics facilities, which include logistics information system.

Consequently, the first stage of management is the choice of marketing strategy and agreeing on territory goals with marketing, then developing a combination of methods for logistics marketing strategy.

Now, combination of territorial marketing strategy and logistical activities shall be presented. 
Of all existing classifications of territorial marketing strategies, we choose the one of A.P. Pankruchin: image marketing, population marketing, infrastructure marketing, and attractiveness marketing. We present here various logistical methods for these marketing strategies (tab. 2).

Tab. 2. Combination of marketing strategies and logistical methods

\begin{tabular}{|c|c|c|c|}
\hline $\begin{array}{l}\text { Marketing } \\
\text { strategy }\end{array}$ & $\begin{array}{l}\text { Purpose of } \\
\text { strategy and marketing } \\
\text { functions }\end{array}$ & Logistical functions & $\begin{array}{l}\text { Planned results and logistical } \\
\text { tactics }\end{array}$ \\
\hline $\begin{array}{l}\text { Image } \\
\text { marketing }\end{array}$ & $\begin{array}{l}\text { Creating a positive } \\
\text { image being attractive } \\
\text { for certain groups of } \\
\text { market customers. } \\
\text { Creating new system } \\
\text { of communication, ad- } \\
\text { vertisements of speci- } \\
\text { fic territorial products }\end{array}$ & $\begin{array}{l}\text { Managing information } \\
\text { streams }\end{array}$ & $\begin{array}{l}\text { Short time of communication, } \\
\text { low costs for advertisements bud- } \\
\text { get, } \\
\text { creating optimum structure of in- } \\
\text { formational support }\end{array}$ \\
\hline $\begin{array}{l}\text { Infrastructure } \\
\text { marketing }\end{array}$ & $\begin{array}{l}\text { Creating the system of } \\
\text { long-time investments } \\
\text { interesting for the ter- } \\
\text { ritory }\end{array}$ & \begin{tabular}{|l|} 
Logistical managing \\
quality of stream proces- \\
ses, realization of logi- \\
stical principles «just in \\
time»
\end{tabular} & $\begin{array}{l}\text { Analyzing material, information, } \\
\text { finance and labor interrelations, } \\
\text { which unite the territory. Selecting } \\
\text { new branches for productional } \\
\text { investments and rational usage of } \\
\text { financial resources }\end{array}$ \\
\hline $\begin{array}{l}\text { Population } \\
\text { marketing }\end{array}$ & $\begin{array}{l}\text { Redistribution of labor } \\
\text { resources among ter- } \\
\text { ritories }\end{array}$ & $\begin{array}{l}\text { Creating optimum sys- } \\
\text { tem and structure of } \\
\text { communications provid- } \\
\text { ing validity of informa- } \\
\text { tion, minimization of } \\
\text { time and migration costs } \\
\text { for future personnel }\end{array}$ & $\begin{array}{l}\text { Creating and developing an opti- } \\
\text { mal transportation system among } \\
\text { territories }\end{array}$ \\
\hline $\begin{array}{l}\text { Attractiveness } \\
\text { marketing }\end{array}$ & $\begin{array}{l}\text { Expanding attractive- } \\
\text { ness of the territory } \\
\text { through tourist busi- } \\
\text { ness services }\end{array}$ & $\begin{array}{l}\text { Management in the } \\
\text { sphere of costs regula- } \\
\text { tion aimed at investing } \\
\text { into construction proj- } \\
\text { ects }\end{array}$ & $\begin{array}{l}\text { Creating an optimum cost system } \\
\text { for investment attractiveness, } \\
\text { optimizing time costs, achieving } \\
\text { harmonious supplies of material } \\
\text { goods, management of quality } \\
\text { production process. } \\
\text { Creating an integrative chain of } \\
\text { consumer goods supplies for tour- } \\
\text { ist business services }\end{array}$ \\
\hline
\end{tabular}

This list of territorial marketing strategies cannot be full. At present, there exist new classifications, which are to be adapted for of logistical management technologies. For achieving a multiplicative effect at territorial development, it is necessary to take into consideration the differences in economic situations.

As an example of using logistical and marketing technologies for economic growth, Singapore can be taken. It is situated on 55 small islands, its area is 622 square kilometers. In 1959, Singapore became the capital, since 1965 the capital of an independent republic. The 
financial condition of Singapore was pitiful at that time; the level of criminality was very high. The young city-state doesn't have mineral, oil or land resources, which could be sold.

What were the main marketing strategies and logistical technologies that helped Singapore government ensure economic possibility?

Singapore's comfortable geographic position was used first of all. That factor has always played the most important role in economic development of this country. This advantage permitted to integrate infrastructure marketing strategy, which included logistical managing of the quality of stream processes and realization of logistical principles «just in time», to create one of the largest trade seaports in the world. Now Singapore has become the second seaport in the world (after Rotterdam), which processes over 400 million tons of loads a year.

The investment was directed at building transport centres, for example a new international airport, attended by more than 50 companies. It was necessary to take measures for selecting new branches of production investments in logistical sphere. Emerging of electrotechnical products, transport equipment, oil refinery production and chemicals industry was the result of these processes.

Secondly, Singapore government designed to develop the city using strategies of attractiveness marketing and image marketing. In the beginning, tourists were attracted by Singapore's national traditions: the history of Merlion - the symbol of Singapore (fig. 2) and by specific parts of this city: «Small India», «Chinatown», or «Dutch village».

The achievement of purposes of marketing strategies was based on creating the image of a safe state, using logistical method «XYZ» to create an optimum cost system for investment attractiveness.

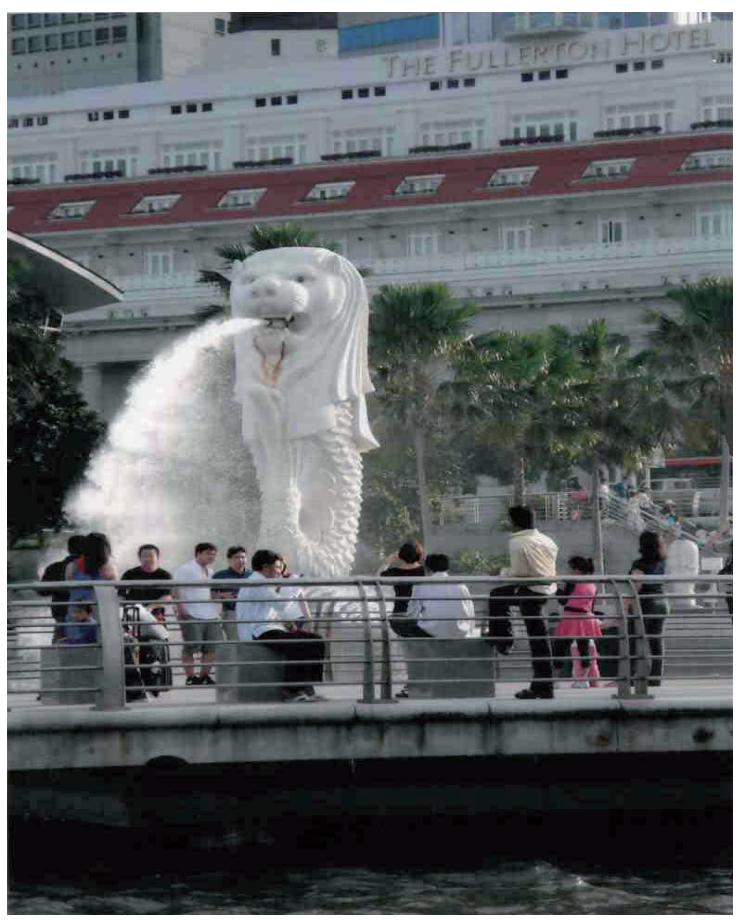

Fig. 2. Statue of Merlion (Lion-Mermaid) - the symbol of Singapore (the author's photo) 
Connection of using logistical methods for optimization of state finances with integrating new systems of taxes provision form undeficited budget. These investments were directed to the tourist business services objects:

- the Singapore butterfly park, the park of birds «Jourong» which has 4.5 thousands of specimens, zoo park - the largest in the world;

- some original museums: the National museum telling of Singapore's history, the Fish Museum, the Museum of Arts, the Fleet Museum.

- a lot of theatres: the Victoria Theatre, the Centre of Drama, the «Black Box».

- new technologies in the sphere of entertainment: the Musical Fountains, air ball to observe, etc.

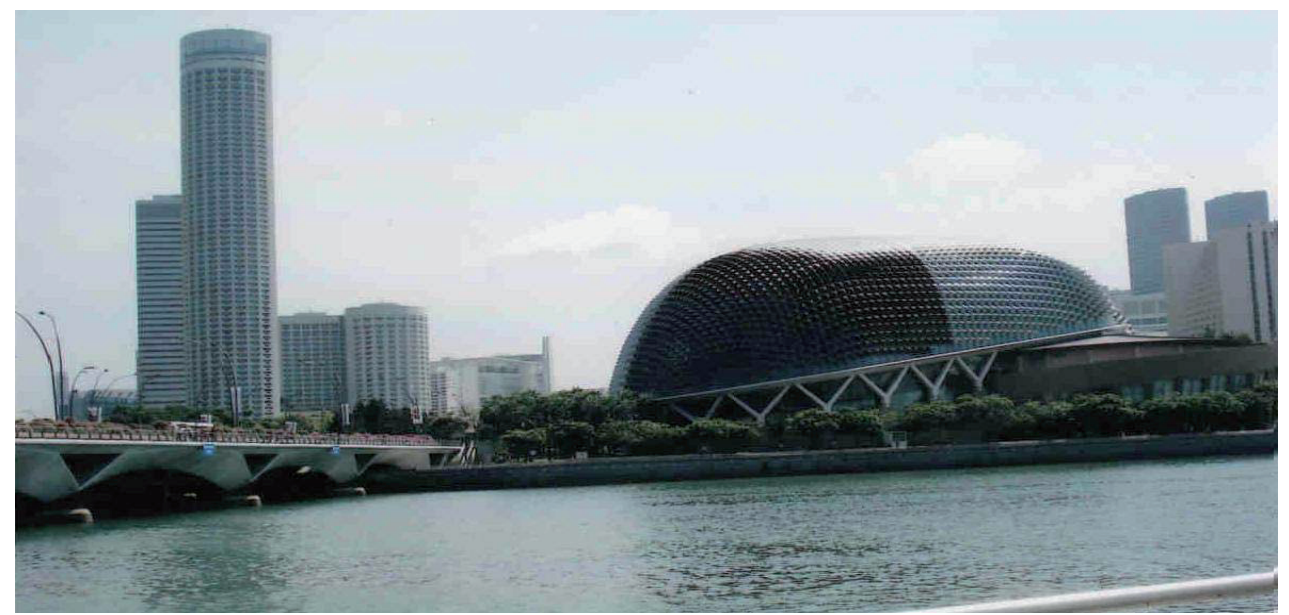

Fig. 3. New Singapore theatre - one of the latest buildings.

It has an original mirror roof (the author's photo)

One of the most important directions in creating industrial and socially developed society was the sphere of public sector and the defense of population. Singapore government is realizing paternalistic policy in this sector of economy.

For example, public transport is managed by the government. The whole taxi park is differentiated into four groups: white and yellow taxis are designed for wealthy groups and are paid at the highest rate, while red and blue ones are the cheapest. The government is realizing programmes to provide the low income groups with a possibility to possess immovable property.

Thus, integrating marketing and logistical strategies have proved to be effective in creating the prosperous economy of Singapore.

\section{References}

Страны и регионы.2006.Статистический справочник Всемирного банка. - М.: Издательство «Весь Мир», 2007. -240 c.

Джонсон Д.С., Дональд Ф. В. Современная логистика. Пер с англ. - М.: Изд. дом. «Вильямс», 2005. $-624 \mathrm{c}$.

Панкрухин А.П. Маркетинг территорий. - СПб.: Питер, 2006. - 406 с. 


\section{Marketing and logistical technologies in creating multiplicative effect of territorial development}

The article is devoted to modern methods and technologies which can be used in development of territorial socio-economic systems. Research in this sphere must serve as the basis of territorial planning. The combination of marketing and logistical technologies is the most effective and progressive in territorial development.

Modern economic integration needs special attention to be paid to conserving and increasing the indicators of socio-economic development, which is a condition of attracting investments from outside.

Certain factors are of high importance for economic development. These factors are logistical in their nature and include: the volume of export and import activities in the structure of gross national revenue; the duration of the period needed for formation of a private business; availability of foreign or domestic investments for financing various economic processes; the level of development of the transportation system.

The experience of Singapore can serve as an example of implementing marketing and logistical technologies in effective development of the territory.

Doc. Oxana Freydman

Irkutsk State Railway University, Russia

e-meil lidink1@hotmail.com 